\title{
PENERAPAN TEKNOLOGI SILASE "FAST-FERMENT" DI PETERNAK KAMBING LOKAL KABUPATEN LAMONGAN
}

\author{
Arif Arya Hertanto ${ }^{1)}$, Edy Susanto ${ }^{2)}$ dan Dyanovita Alkurnia ${ }^{3)}$ \\ 1) Program Studi Peternakan Fakultas Peternakan Universitas Islam Lamongan \\ 2) Fakultas Peternakan Universitas Islam Lamongan. \\ Jl.Veteran No.53.A Lamongan
}

\begin{abstract}
ABSTRAK
Khalayak sasaran kegiatan ini adalah Petani Peternak yang tergabung dalam organisasi mitra Kelompok Tani "Rukun Tani II" dan Kelompok Ternak "Telaga Ternak Mandiri" di desa Tlogoagung, kecamatan Kembangbahu, Kabupaten Lamongan. Metode pendekatan yang digunakan adalah : pemetaan potensi lokasi, penyuluhan berkerjasama dengan Dinas Peternakan dan Kesehatan Hewan Kabupaten Lamongan, penyediaan sarana yang dibutuhkan, pelatihan dan pendampingan pengolahan limbah pertanian dengan teknologi Fast-Ferment. Teknologi Fast-Ferment (Fermentasi Cepat) adalah metode fermentasi limbah pertanian pada kondisi terkontrol dan dalam waktu yang relatif cepat karena menggunakan bio katalisator. Hasil kegiatan menunjukkan bahwa teknologi FasrFerment dengan manajemen buffer stock sangat tepat guna dalam mengatasi permasalahan peternak sapi potong di saat musim kemarau. Kegiatan penyuluhan, penyediaan sarana, pelatihan dan manajemen pengelolaan kegiatan di tingkat kelompok mitra berjalan cukup baik. Diperlukan program pendampingan lebih lanjut terhadap kegiatan kelompok mitra khususnya kegiatan pengelolaan usaha produksi silase dan distribusinya baik di tingkat anggota maupun pasar di luar anggota. Program penelitian juga perlu dilakukan untuk membantu penyelesaian masalah yang muncul serta inovasi teknologi yang diperlukan.
\end{abstract}

Kata Kunci : Kambing Lokal, Fast-Ferment, Silase, Fermentasi

\section{PENDAHULUAN}

Kabupaten Lamongan merupakan
daerah Agro-Maritim yang sebagian besar
masyarakatnya mempunyai ternak sapi potong
sebagai usaha sambilan. Sistem Integrasi
Tanaman-Ternak sejauh ini sangat baik untuk
dilakukan. Potensi limbah pertanian yang
sangat besar adalah modal utama
pengembangan ternak ini. Luas areal lahan
pertanian di Kabupaten Lamongan mencapai
125.565 hektar (BPS dan Dinas Pertanian dan
Kehutanan Kabupaten Lamongan, 2016).
Desa Tlogoagung merupakan salah satu
desa yang terletak di Kabupaten Lamongan
bagian selatan. Lokasi desa ini sekitar 20 Km
arah selatan kota Lamongan. Data monografi
desa Tlogoagung (2013) menunjukkan bahwa
populasi penduduk berjumlah 2.370 orang.
Penduduk yang mempunyai mata pencaharian
dibidang pertanian sebanyak 631 KK. Luas
lahan pertanian mencapai 350 hektar dimana
$60 \%$ nya (210 ha) adalah sawah berpengairan
semi teknis untuk 2 kali tanam padi. Potensi
limbah pertaniannya juga sangat besar. Jumlah
jerami padi yang dihasilkan mencapai 2750 ton/tahun serta dedak halus mancapai 550 ton/tahun. Hal ini setara dengan kemampuan pemenuhan kebutuhan temak sapi potong sebanyak 600 unit ternak (UT)/tahun. Selain itu, limbah tanaman lainnya yang cukup melimpah adalah tebon jagung dan pucuk tebu. Hampir $50 \%$ para petani di desa ini juga mempunyai usaha pendukung berupa ternak khususnya sapi potong.

Kelompok Tani "Rukun Tani II" dan Kelompok Ternak "Telaga Ternak Mandiri" merupakan kelembagaan yang berfungsi sebagai organisasi petani dan peternak di desa Tlogoagung. Salah satu tujuan didirikannya kelompok tersebut adalah sebagai wadah silaturahmi dan tukar pengalaman antar warga petani-peternak khususnya tentang usaha Pertanian dan budidaya Kambing Lokal.

Desa Tlogoagung yang berada di kabupaten Lamongan yang secara klimatologis beriklim kering. Hal ini menimbulkan masalah bagi penyediaan pakan untuk usaha ternak sapi potong. Ketersediaan hijauan pakan tidak bisa kontinyu sepanjang tahun. Pada saat musim kemarau ketersediaan hijauan pakan ternak sangat tidak mencukupi, sedangkan 
pada musim hujan keberadaan hijauan pakan ternak ini sangat berlimpah, dan belum bisa dimanfaatkan sepenuhnya dengan baik. Akibatnya masalah pakan yang merupakan $70 \%$ dari faktor biaya produksi (Bundy and Diggins, 1958) sangat menghambat perkembangan usaha budidaya Kambing Lokal di daerah ini.

Selama ini beberapa peternak sudah ada yang mengumpulkan bahan pakan untuk stok (persediaan) di musim kemarau. Namun keterbatasan lokasi kandang yang sempit menyebabkan jumlah yang disimpan tidak cukup banyak. Hal ini ditambah dengan teknologi yang digunakanpun masih tradisional yaitu dalam bentuk kering (hay) seperti : Jerami padi, jerami kedelai dan tebon jagung. Bahan pakan tersebut biasanya diberikan sebagai pakan utama, sedangkan pemberian bahan penguat seperti dedak halus maupun konsentrat masih sangat minim. Kondisi tersebut menyebabkan hasil pertambahan bobot badan Kambing lokal sangat sedikit bahkan cenderung menurun. Sehingga pada musim kemarau banyak terjadi penjualan ternak secara besar-besaran akibat sulitnya mencari pakan, dan apabila memaksakan untuk beternak justru akan membuat rugi petani peternak. Diperlukan kegiatan untuk pengelolaan limbah pertanian untuk mencukupi kebutuhan pakan di daerah tersebut.

\section{METODE PELAKSANAAN}

\section{Lokasi dan Waktu}

Kegiatan ini dilaksanakan di kelompok Mitra yaitu : 1) Kelompok Tani "Rukun Tani II" dan Kelompok Petani Peternak "Telaga Ternak Mandiri" yang beralamat di Desa Tlogoagung
Kecamatan Kembangbahu Kabupaten Lamongan. Dilaksanakan pada tanggal 03 April sampai dengan 2 Agustus 2018.

\section{Metode Pendekatan}

Berdasarkan kondisi dan prioritas masalah yang ada maka perlu dilakukan penyelesaian masalah melalui beberapa metode pendekatan diantaranya: 1) Pemetaan kondisi teknis ketersediaan bahan pakan sepanjang tahun di desa Tlogoagung kecamatan Kembangbahu kabupaten Lamongan. 2) Penyuluhan tentang teknologi Fast-Ferment, Kerja sama dengan Dinas Peternakan dan Kesehatan Hewan Kabupaten lamongan. 3) Pelatihan pembuatan silase dari Jerami padi, tebon jagung dan pucuk tebu dengan teknologi Fast Ferment. 4) Pelatihan perbanyakan growth promotor. 5) Penyediaan peralatan pembuatan silase di kelompok mitra. 6)Penyediaan tempat penyimpanan stok pakan untuk musim kemarau berupa Gudang Penyangga pakan (buffer) yang dikelola oleh kelompok mitra. 7) Pendampingan (bimbingan teknis) tentang keberlanjutan produksi silase dan growth promotor di tingkat kelompok.

\section{HASIL DAN PEMBAHASAN}

\section{Hasil Persiapan Kegiatan}

Hal pertama yang dilakukan dalam kegiatan ini adalah sosialisasi rencana kegiatan kepada anggota kelompok mitra dalam hal ini adalah Kelompok Tani Rukun Tani II dan Kelompok Petani Peternak Telaga Ternak Mandiri. Kegiatan yang telah dilakukan tersebut terlihat pada gambar 1.

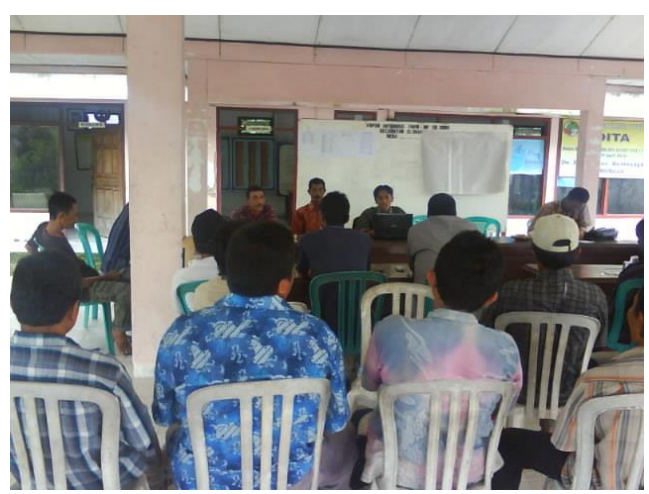

Gambar 1. Sosialisasi Rencana Kegiatan di Kelompok Tani “Rukun Tani II” dan Kelompok Petani Peternak "Telaga Ternak Mandiri"

Kegiatan sosialisasi ini dihadiri oleh anggota Kelompok tani "Rukun Tani II" dan anggota Kelompok Petani Peternak "Telaga Ternak Mandiri" di Desa Tlogoagung
Kecamatan Kembangbahu Kabupaten Lamongan. Semua yang hadir tersebut mempunyai kriteria yang telah ditentukan diantaranya : kepemilikan ternak dan lama 
beternak. Kegiatan ini mampu menjelaskan secara detail permasalahan, tujuan dan bentuk kegatan yang akan dilaksanakan, sekaligus mengkonfirmasi hal-hal yang kiranya diperlukan lebih lanjut. Menurut Vander Zanden, sosialisasi adalah proses interaksi sosial melalui mana kita mengenal cara-cara berpikir, berperasaan dan berperilaku, sehingga dapat berperan serta secara efektif dalam masyarakat (Ihromi, 1999 ; Harada, 2011).

Persiapan berikutnya adalah penyediaan sarana yang dibutuhkan diantaranya : silo dalam bentuk tong plastik dengan spesifikasi Jenis Plastik : HD Ukuran: $60 \mathrm{~cm} \times 120 \mathrm{~cm} \times 0.5$ $\mathrm{cm}$, Volume : 0.02m3, Warna : biru yang disajikan dalam gambar 2 .

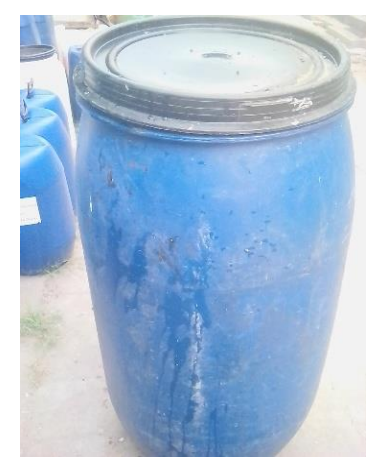

\section{Gambar 2. Silo "Tong Plastik" untuk menyimpan Silase}

Silo tong plastik dipilih karena lebih efektif dan efisien karena lebih murah, mudah didapat, efisien dalam penyimpanan dan tepat dalam penggunaan silase yang akan diberikan kepada kambing sehingga bisa bertahan dalam jangka waktu yang lama. Susanto, dkk. (2014) menjelaskan bahwa silo dapat dibuat dengan berbagai macam bentuk tergantung pada
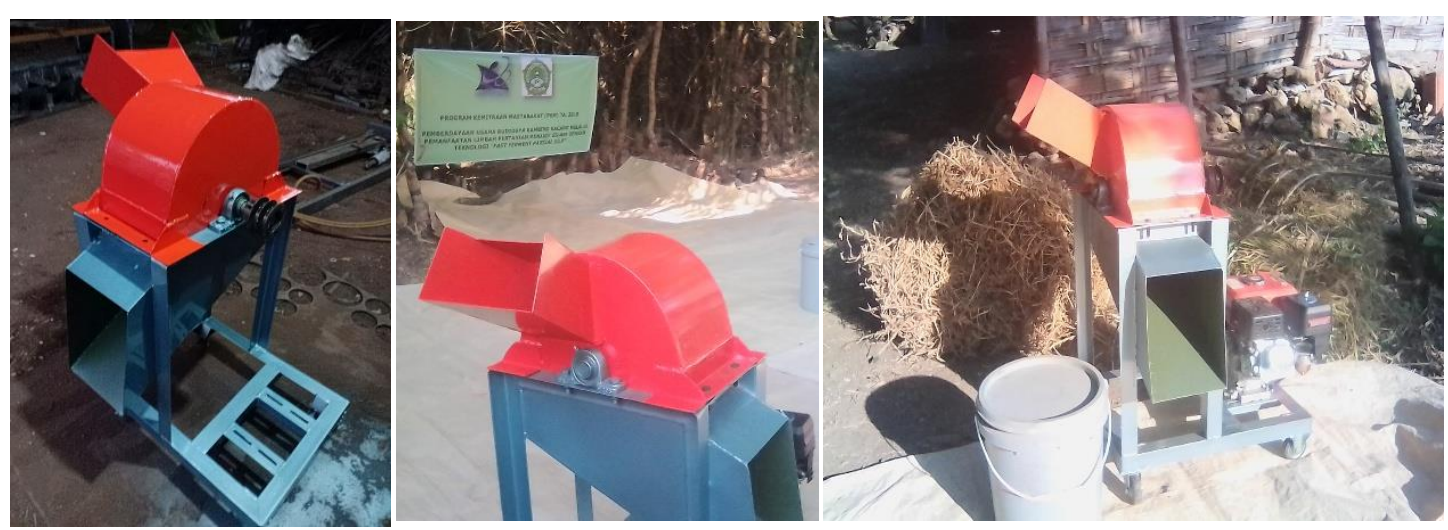

Gambar 3. Chopper beserta mesin penggerak 6,5 HP

Alat tersebut mempunyai spesifikasi : Kapasitas 200 - 300 kg / jam, Dimensi mesin : P $1200 \mathrm{~cm}, \mathrm{~L} 70 \mathrm{~cm}$. T $110 \mathrm{~cm}$ Bahan body : mild steel tebal $3 \mathrm{~mm}, 2 \mathrm{~mm}, 10 \mathrm{~mm}$, Bahan rangka : UNP $65 \mathrm{~mm}$, Besi Siku $50 \mathrm{~mm}$, Mata pisau : Baja dan Mesin penggerak : Deasel 6,5 HP. Pemotongan hijauan berfungsi untuk lokasi, kapasitas, bahan yang digunakan dan luas areal yang tersedia.

Sarana lain yang dipersiapkan adalah pencacah hijauan (chopper) seperti pada gambar 3 berikut ini : 

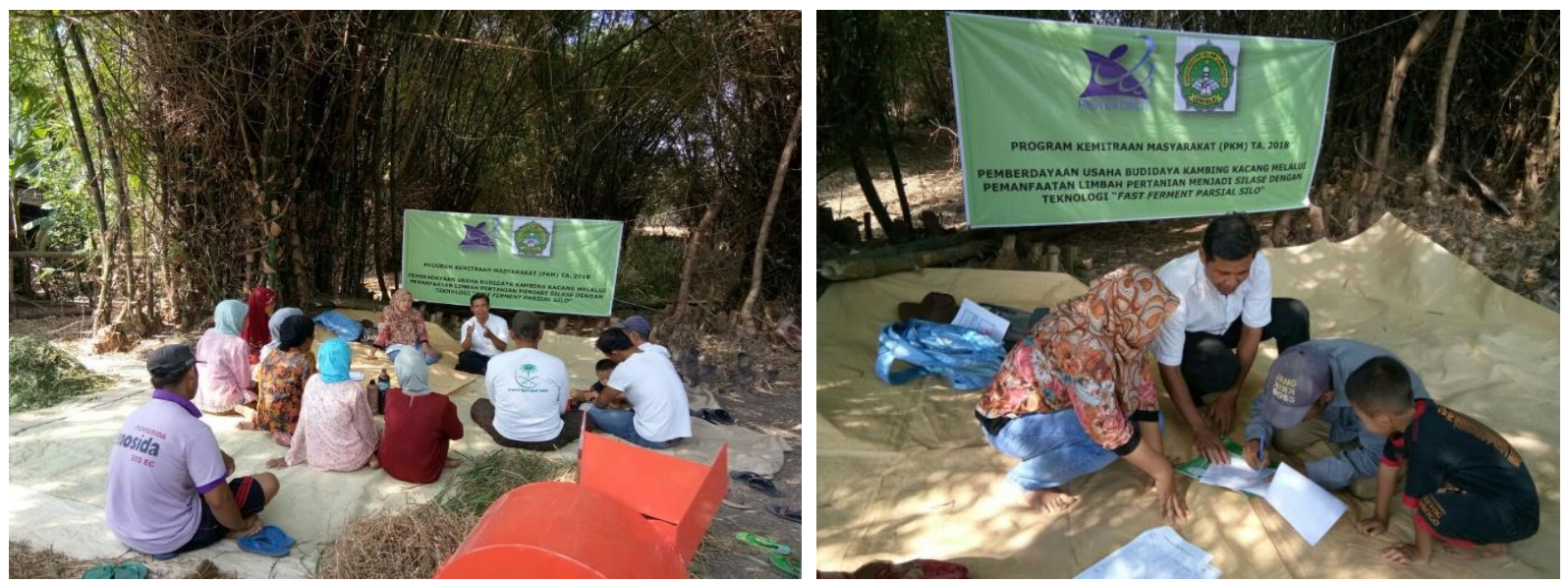

Gambar 4. Kegiatan Penyuluhan I di Kelompok Mitra

Sebelum dilaksanakan penyuluhan, peserta diajak untuk mengerjakan soal pre-test. Hasil pre-test menunjukkan bahwa nilai yang dicapai peserta rata-rata sebesar 44,5 nilai yang rendah tersebut menunjukkan bahwa tingkat pengetahuan peserta terhadap teknologi pakan ternak masih sangat rendah.

Kegiatan penyuluhan I dilakukan untuk meningkatkan pengetahuan berdasarkan hasil pre-test yang dicapai. Materi yang diberikan adalah tentang dasar-dasar teknologi pengawetan pakan dan prinsip-prinsip pembuatan silase. Kegiatan ini dihadiri oleh 20 orang peserta dari kelompok tani "Rukun Tani II" dan kelompok petani-peternak "Telaga Ternak Mandiri" Desa Tlogoagung Kecamatan Kembangbahu Kabupaten Lamongan.

Kegiatan penyuluhan dilakukan dua kali. Penyuluhan II dilaksanakan sehari selanjutnya untuk menambah wawasan lebih luas dan aplikatif. Kegiatan tersebut bisa dilihat pada gambar 5 .

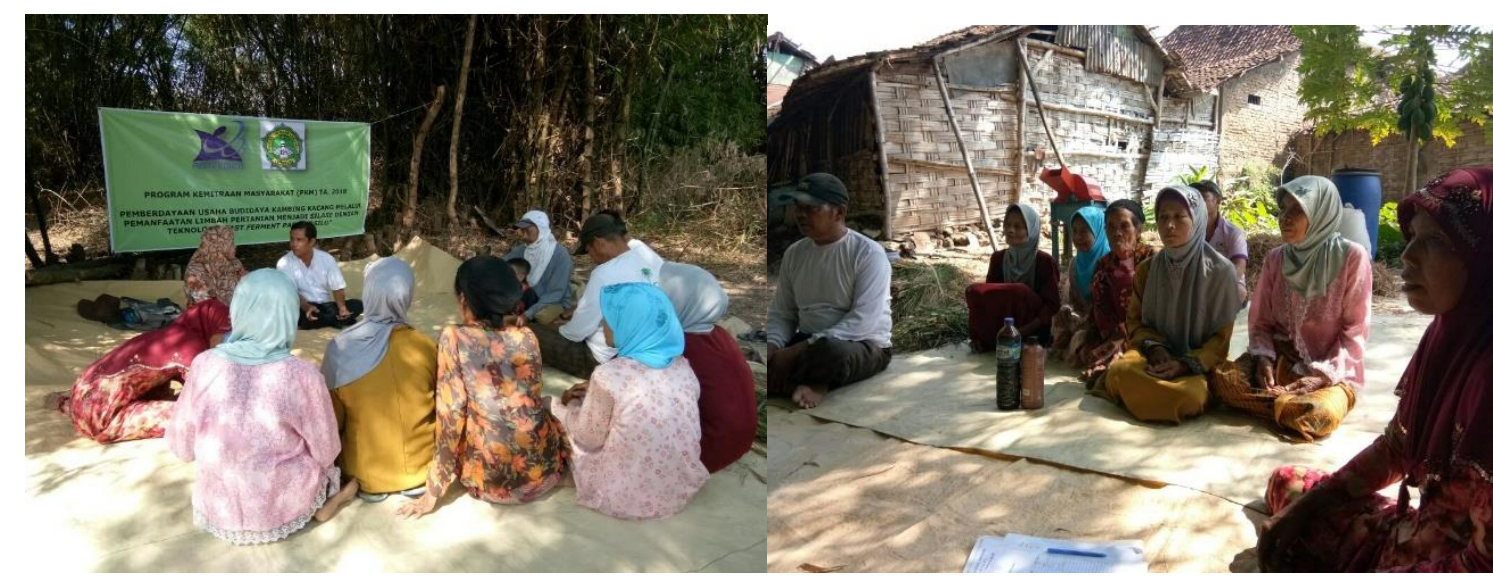

Gambar 5. Kegiatan Penyuluhan II di Kelompok Mitra

Kegiatan penyuluhan II menerangkan materi tentang cara teknis pembuatan silase. Setelah mengikuti kegiatan tersebut peserta lebih paham terhadap cara-cara pembuatan silase dengan teknologi Fast Ferment. Sehingga siap secara pengetahuan untuk melakukan praktek dalam kegiatan pelatihan pembuatan silase.

\section{Hasil Kegiatan Pembuatan Silase}

Kegiatan pelatihan diharapkan mampu memberikan keterampilan dasar dalam pembuatan silase dengan teknologi yang diterapkan. Pertama yang disiapkan dalam rangka pembuatan silase adalah mempersiapkan limbah pertanian yang akan dibuat silase. Kegiatan tersebut tersaji pada gambar 6 . 

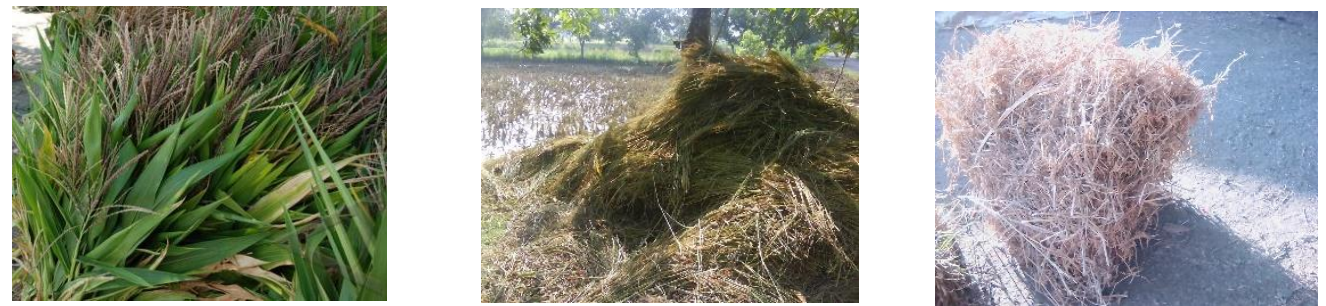

Gambar 6. Limbah pertanian (tebon jagung, jerami padi dan Jerami Kedelai)

Limbah pertanian tersebut diperoleh dari daerah sekitar lokasi kelompok mitra. Pada bulan juni 2018 merupakan musim panen MK I sehingga ketersediaan limbah pertanian tersebut sangat melimpah. Limbah pertanian yang disiapkan antara lain tebon jagung sebesar 1 ton, jerami padi sebesar 1,5 ton dan jerami kedelai sebasar 0,5 ton.

Kegiatan berikutnya adalah pelatihan dan pembuatan silase bersama peserta. Kegiatan tersebut seperti pada gambar 7 .
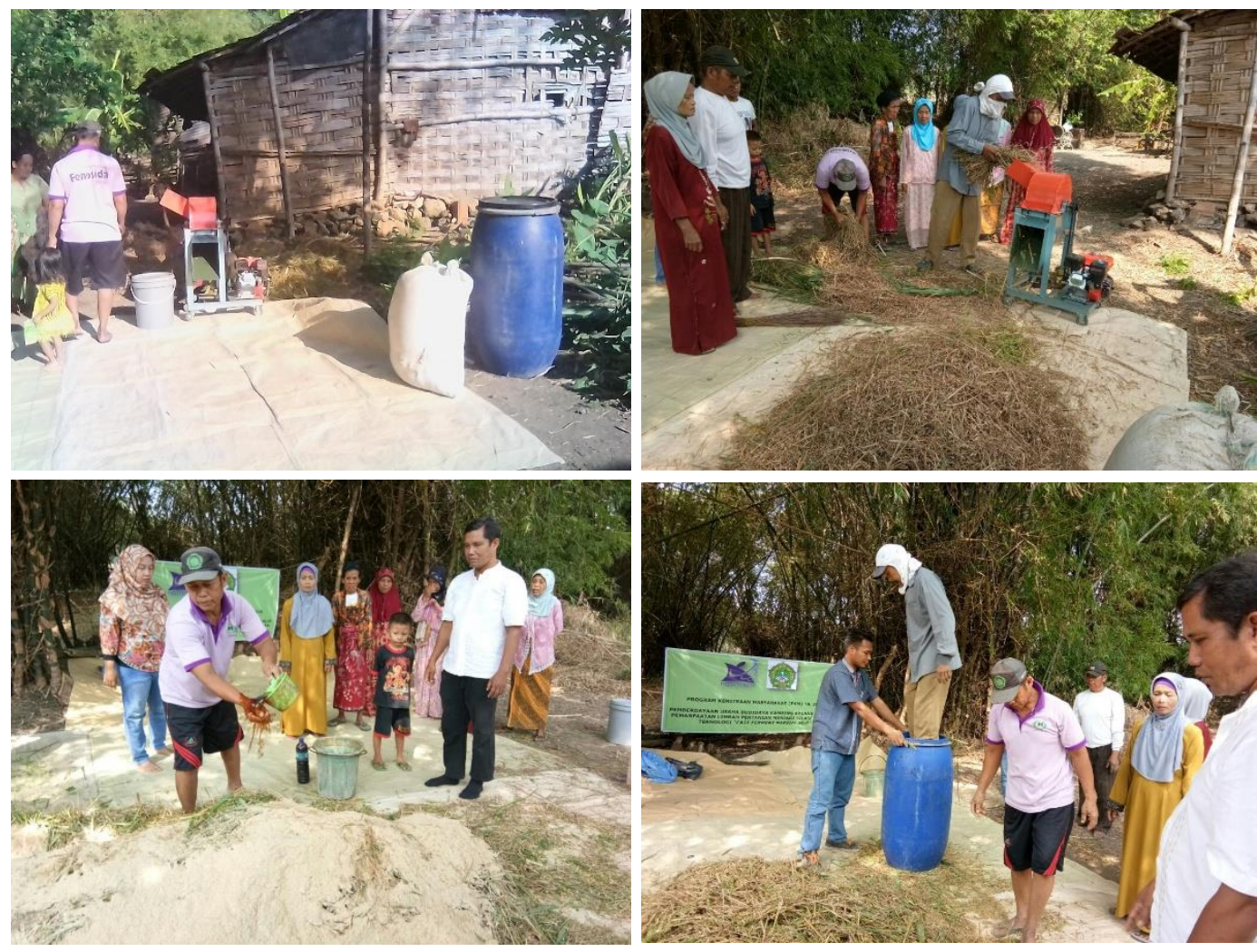

Gambar 7. Kegiatan pelatihan dan pembuatan silase

Prosedur yang dilakukan dalam kegiatan pelatihan dan pembuatan silase di kelompok mitra sesuai Pioner Development Foundation (1991) adalah sebagai berikut :

1. Pembuatan Silase Jerami Padi dengan teknologi Fast Ferment

a. Jerami padi dipotong-potong / chopper, ukuran $3-5 \mathrm{~cm}$ b. Ditambahkan Growth Promotor 1,5 lt/ 1,5 ton jerami padi yang dilarutkan kedalam 7,5 kg molases dan 120 liter air.

c. Dimasukkan kedalam (silo) tong plastik

d. Tumpukan Jerami padi dipadatkan

e. Ditutup rapat dan disimpan 
2. Pembuatan Silase Tebon Jagung dengan teknologi fast ferment
a. Tebon Jagung dipotong-potong / chopper, ukuran 3-5 cm
b. Ditambahkan Growth Promotor 1 It/ 1 ton tebon jagung yang dilarutkan kedalam $5 \mathrm{~kg}$ molases dan 60 liter air.
c. Dimasukkan kedalam (silo) tong plastik
d. Tumpukan tebon jagung dipadatkan
e. Ditutup rapat dan disimpan

3.Pembuatan Silase jerami kedelai dengan teknologi fast ferment

a. Jerami kedelai dipotong-potong chopper, ukuran 3-5 cm

b. Ditambahkan Growth Promotor 0,5 It/ 0,5 ton jerami kedelai yang dilarutkan kedalam $2,5 \mathrm{~kg}$ molases dan 50 liter air.

c. Dimasukkan kedalam (silo) tong plastik d. Tumpukan jerami kedelai dipadatkan

e. Ditutup rapat dan disimpan

Hasil kegiatan ini menunjukkan bahwa peserta telah mampu mengikuti kegiatan dengan baik sehingga menghasilkan silase yang aman dan bisa diberikan kepada ternak.

\section{Hasil Kegiatan Perbanyakan Growth Promotor}

Salah satu komponen penting dalam pembuatan silase adalah starter yang berisi mikroba pengurai sekaligus sebagai pemacu pertumbuhan (growth promotor). Selama ini produk tersebut masih harus dibeli dengan harga yang cukup mahal. Hal ini bisa disiasati dengan memperbanyak starter tersebut. Kegiatan memperbanyak growth promotor bisa dilihat pada gambar 8 .
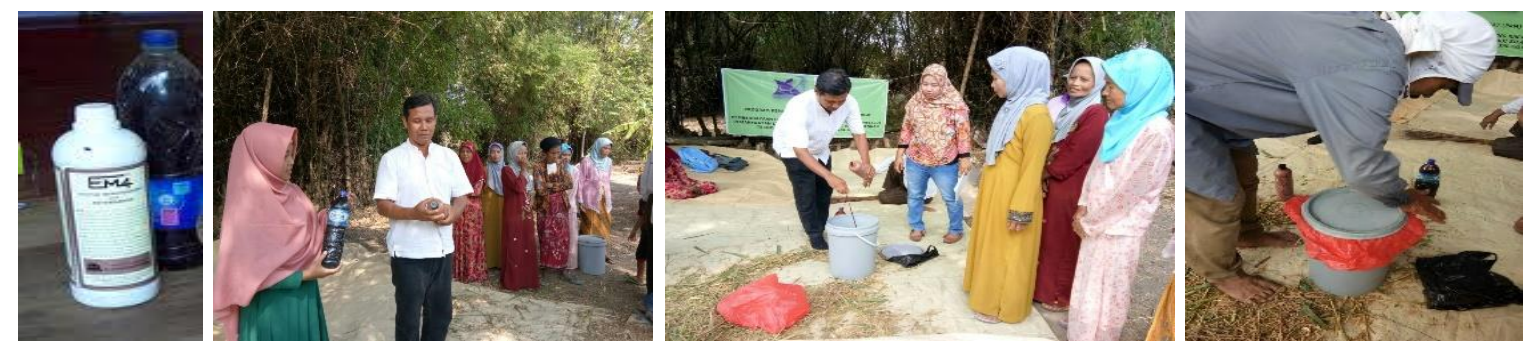

\section{Gambar 8. Kegiatan Perbanyakan growth promotor}

Prosedur perbanyakan growth promotor sesuai Dhariyan (2010) pada kegiatan ini dilakukan dengan cara : menyiapkan 1 liter starter bio katalisator merek Em4, kemudian melarutkan $5 \mathrm{~kg}$ molases ke dalam 100 liter air ke dalam drum plastik. Setelah itu dimasukkan starter kemudian dan diaduk sampai homogen. Setelah itu drum ditutup rapat dan diinkubasi selama 7 hari. Setelah proses fermentasi selesai maka produk dipindahkan ke botol 1 liter-an, kemudian disimpan.

\section{Pemberian Silase pada Ternak Kambing Lokal}

Produk silase hasil kegiatan ini juga diuji coba pada ternak kambing lokal. Kegiatan tersebut bisa dilihat pada gambar 9 .
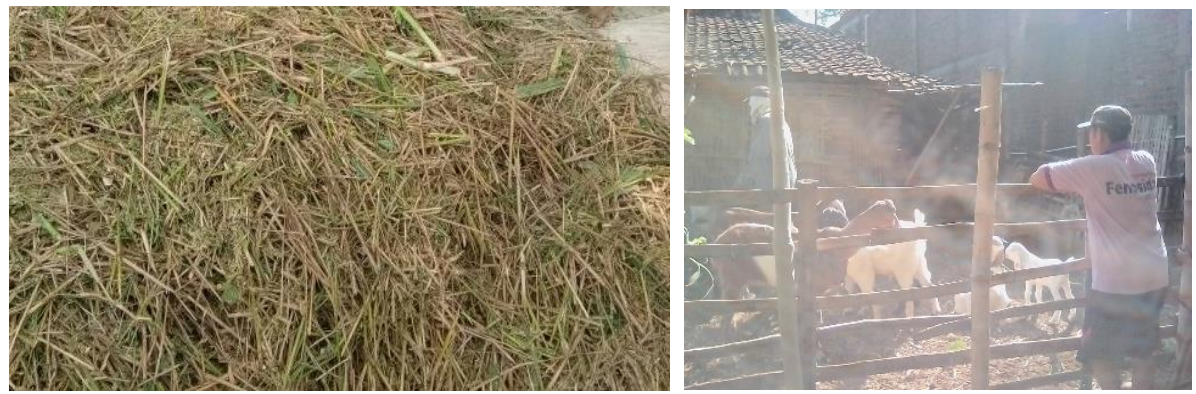

Gambar 9. Pemberian silase pada ternak kambing lokal

Silase yang dihasilkan pada kegiatan ini mempunyai karakteristik fisik : berbau khas fermentasi dan berwarna tetap hijau agak kekuningan. Ternak yang akan diberi pakan silase ini adalah kambing lokal jenis kacang. sebelum diberikan, silase dari silo plastik diangin-anginkan dulu selama 1 jam. Hasil pengamatan diketahui bahwa tingkat kesukaan (palatabilitas) kambing kacang terhadap silase adalah cukup tinggi.

\section{Buffer Stock Silase Di Gudang Kelompok Mitra}


Setelah produk silase yang dihasilkan dari kegiatan ini telah jadi, maka dilakukan penyimpanan di gudang penyangga sebagai buffer stock petani-peternak di musim kemarau. Hal tersebut bisa dilihat pada gambar 10 . 


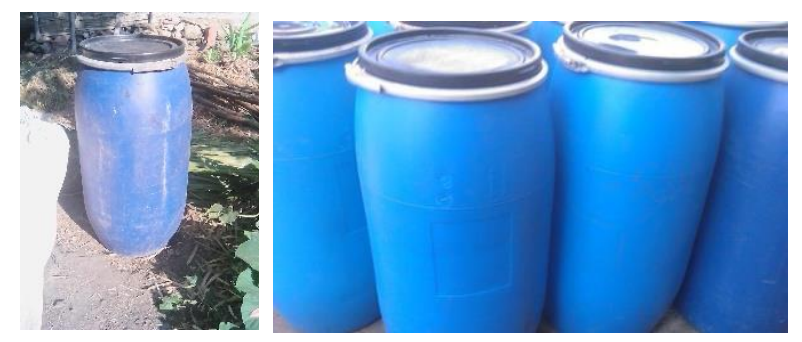

Gambar 10. Buffer Stock Silase

Hasil produk silase disimpan dalam silo plastik kemudian di tumpuk dan disimpan di dalam gudang penyangga milik salah satu anggota kelompok. Produk tersebut akan digunakan saat puncak musim kemarau (bulan september - oktober) tahun 2018 yang akan datang.

\section{KESIMPULAN}

teknologi Fast_Ferment dengan manajemen Parsial Silo sangat tepat guna dalam mengatasi permasalahan peternak sapi potong di saat musim kemarau. Kegiatan penyuluhan, penyediaan sarana, pelatihan dan manajemen pengelolaan kegiatan di tingkat kelompok mitra berjalan cukup baik.

\section{UCAPAN TERIMA KASIH}

Terima kasih sebesar besarnya kami sampaikan kepada DRPM Kementerian Riset, Teknologi dan Pendidikan Tinggi RI atas didanainya Program Kemitraan Masyarakat (PKM) Tahun 2018. Juga kepada Litbang Pemas dan Pimpinan Universitas Islam Lamongan atas dukungan dan fasilitas yang diberikan selama proses pelaksanaan hingga pelaporan.

\section{REFERENSI}

Bundy, C.E.and R.V.Diggins, 1958. Beef Production. Prentice-Hall, Inc., Englewood Cliffs, New York.

Dhariyan, 2010. Prosedur Memperbanyak Growth Promotor. http//www.biotani.com. diakses 6 april 2012.

Hanafi, N.D., 2008. Teknologi Pengawetan Pakan. Departemen Peternakan. Fakultas Pertanian. Universitas Sumatera Utara. Medan.

Harada, N., 2011. Konsep Sosialisasi. http://repository.usu.ac.id/bitstream/1 23456789/

30058/3/Chapter\%20II.pdf. diakses : 02 juli 2014.

Pioner Development Foundation. 1991. Silage Technology. A.Trainers Manual. Pioner Development Foundation for Asia and The Pacific Inc. : $15-24$.

Susanto, E., Mufid, D., Wahyuning, D., 2014. pembuatan silase dengan teknologi "sup-fersi" di peternak sapi potong kabupaten lamongan. Jurnal Ternak 5 (2), 8 - 15. http://iournal.unisla.ac.id/pdf/1852201 4/edy\%20susanto\%20dan\%20mufid \%20dahlan\%20dan\%20dyah\%20wa hyuning\%20a.pdf 